\title{
Inhibition of transketolase by oxythiamine altered dynamics of protein signals in pancreatic cancer cells
}

\author{
Jiarui Wang ${ }^{1,5 \dagger}$, Xuemei Zhang ${ }^{6}$, Danjun Ma ${ }^{1+}$, Wai-Nang Paul Lee ${ }^{2}$, Jing Xiao ${ }^{1}$, Yingchun Zhao ${ }^{1}$,
} Vay Liang Go ${ }^{2}$, Qi Wang ${ }^{3^{*}}$, Yun Yen ${ }^{4}$, Robert Recker ${ }^{1}$ and Gary Guishan Xiao ${ }^{1^{*}}$

\begin{abstract}
Oxythiamine (OT), an analogue of anti-metabolite, can suppress the nonoxidative synthesis of ribose and induce cell apoptosis by causing a G1 phase arrest in vitro and in vivo. However, the molecular mechanism remains unclear yet. In the present study, a quantitative proteomic analysis using the modified SILAC method (mSILAC) was performed to determine the effect of metabolic inhibition on dynamic changes of protein expression in MIA PaCa-2 cancer cells treated with OT at various doses $(0 \mu \mathrm{M}, 5 \mu \mathrm{M}, 50 \mu \mathrm{M}$ and $500 \mu \mathrm{M})$ and time points $(0 \mathrm{~h}, 12 \mathrm{~h}$ and $48 \mathrm{~h})$. A total of 52 differential proteins in MIA PaCa-2 cells treated with OT were identified, including 14 phosphorylated proteins. Based on the dynamic expression pattern, these proteins were categorized in three clusters, straight down-regulation (cluster 1, 37\% of total proteins), upright "V" shape expression pattern (cluster 2, 47.8\% total), and downright " $\mathrm{V}$ " shape pattern (cluster 3, 15.2\% total). Among them, Annexin A1 expression was significantly downregulated by OT treatment in time-dependent manner, while no change of this protein was observed in OT dosedependent fashion. Pathway analysis suggested that inhibition of transketolase resulted in changes of multiple cellular signaling pathways associated with cell apoptosis. The temporal expression patterns of proteins revealed that OT altered dynamics of protein expression in time-dependent fashion by suppressing phosphor kinase expression, resulting in cancer cell apoptosis. Results from this study suggest that interference of single metabolic enzyme activity altered multiple cellular signaling pathways.
\end{abstract}

Keywords: Quantitative proteomics, Pancreas cancer, ${ }^{15} \mathrm{~N}$ stable isotope, Phosphorylation, Turnover rate, Metabolic inhibitor, Metabolic therapy, Transketolase, Oxythiamine

\section{Introduction}

It has been known for decades that most tumor cells and tissues enhanced glucose metabolism by glycolysis $[1,2]$. Although its causal relationship with cancer cell proliferation is still unclear, the phenomenon has been developed a reliable technique for detecting and classifying tumors by fluorodeoxyglucose positron emission tomography (FDG-PET) [3,4]. In recent years, this metabolic alteration of malignant cells has been observed in

\footnotetext{
*Correspondence: wqdmu@yahoo.com.cn; gxiao@creighton.edu

${ }^{\dagger}$ Equal contributors

${ }^{3}$ Department of Respiratory Medicine, Dalian Medical University, Dalian 116027, China

${ }^{1}$ Genomics \& Functional Proteomics Laboratories, Osteoporosis Research Center, Creighton University Medical Center, 601 N 30th ST, Suite 6730, Omaha, NE 68131, USA

Full list of author information is available at the end of the article
}

multiple cancer cells, and it has become an important aspect for design of anticancer drugs that inhibits glycolysis and other relevant metabolic processes. Several small molecules, including 2-deoxyglucose, lonidamine, 3-bromopyruvate, imatinib and oxythiamine (OT), have shown the effectiveness in anticancer activity in vitro and in vivo [5-16]. They are currently in the clinical and pre-clinical phase. Some other compounds also exhibit potential anticancer activity by modulating glucose metabolism [16].

OT is a thiamine antagonist and inhibits transketolase (TK) which is an enzyme of the pentose phosphate pathway in animals. As transketolase reaction plays a vital role of the pentose phosphate pathway, inhibition of transketolase will suppress the pentose phosphate pathway and interrupt the synthesis of these important

\section{Biomed Central}

(c) 2013 Wang et al.; licensee BioMed Central Ltd. This is an Open Access article distributed under the terms of the Creative Commons Attribution License (http://creativecommons.org/licenses/by/2.0), which permits unrestricted use, distribution, and reproduction in any medium, provided the original work is properly cited. 
coenzymes ATP, CoA, NAD $(\mathrm{P})+$, FAD, and genetic material, RNA and DNA in cancer cells. OT can suppress the nonoxidative synthesis of ribose and cause cell apoptosis by inducing a G1 phase arrest in vitro and in vivo $[14,15,17,18]$. Although the exactly molecular mechanism is not clear, it has been accepted that the decreased biological macromolecular synthesis can inhibit cell proliferation and induces cell apoptosis. Therefore, these features of metabolism are actually used for cancer therapeutic approach known as "metabolic therapy" $[19,20]$.

In the present study, a dynamic proteomic method was adapted to analyze the effects of antimetabolite OT on dynamic changes of protein expression in pancreatic cancer cells, thus to understand the molecular mechanism underlying antimetabolite interference.

\section{Materials and methods}

\section{Chemicals and regents}

${ }^{15} \mathrm{~N}$ enriched algal amino acid mixture $\left({ }^{15} \mathrm{~N}\right.$ enrichment, 98\%) was purchased from Cambridge Isotope Laboratory Inc. (Andover, MA). Fetal bovine serum (FBS) was purchased from Irvine Scientific (Santa Ana, CA). Dulbecco's modified Eagles's medium and antimycotic were from Gibco (Calsbad, CA). Sequence grade trypsin solution was from Promega (Madison, WI).

Acetonitrile was purchased from Thermo Fisher Scientific (Rockford, IL). Materials employed for gel electrophoresis were purchased from BioRad. Water was prepared using a Milli-Q system (Millipore, Bedford, MA). Other chemicals employed were purchased from Sigma (St. Louis, MO). This project was approved by Creighton University Institutional Review Board.

\section{In vitro cytotoxic activity}

The cell cytotoxicity of OT against the MIA PaCa-2 cells was determined by MTT assay [21,22]. The cells at exponential phase were dispensed in 96-well plates at a density of $1 \times 10^{4}$ cells per well. The cells were stimulated with different concentrations of OT for 2 days. The cells were then incubated in $20 \mu \mathrm{l}$ MTT (3-(4, 5-dimethylthiazol2-yl)-2, 5-diphenyl tetrazolium bromide) (Sigma, USA) in growth medium at $37^{\circ} \mathrm{C}$ for $4 \mathrm{~h}$ lysed in $100 \mu \mathrm{l}$ of dimethyl sulfoxide (Sigma, USA) for $10 \mathrm{~min}$. The absorbance in each well was measured at $490 \mathrm{~nm}$ by an ELx800 Absorbance Microplate Reader (Biotek, CA). The cell viability and $\mathrm{IC}_{50}$ value were calculated by the following equations: cell viability $=$ mean optical density of experimental group/ mean of the control $\times 100 \%$; $\mathrm{IC}_{50}$ value $=$ concentration of OT at $50 \%$ cell viability.

\section{Cell culture}

Human pancreatic carcinoma cell line MIA PaCa-2 was maintained in MEM supplemented with $10 \%$ fetal bovine serum and $1 \%$ antibiotic antimycotic at $37^{\circ} \mathrm{C}$ in $5 \% \mathrm{CO} 2$ until $80 \%$ confluence when the experiment started $[23,24]$. Experiments were set up in two groups: doseand time-dependent groups. For the dose-dependent group, the cells were stimulated with 5, 50 and $500 \mu \mathrm{M}$ OT for 48 hours, respectively. The unstimulated cells were considered as control. For the time-dependent group, the cells were stimulated with $50 \mu \mathrm{M}$ OT in MEM containing natural amino acids or $50 \%$ of ${ }^{15} \mathrm{~N}$ algal amino acid mixture $\left({ }^{15} \mathrm{~N}\right.$ enrichment, 98\%) for 12 and $48 \mathrm{~h}$. The unstimulated cells were considered as the zero time point. Each treatment was repeated four times with $10 \mathrm{~mL} /$ flask. The cell pellets were then collected for further analysis.

\section{Protein sample preparation}

The cell pellets were immediately washed three times with ice-cold PBS. Cells were harvested in 2-DE lysis buffer with protease inhibitor set III and phosphatase inhibitor set II (Calbiochem, La Jolla, CA). The suspension was sonicated at 100 Watt for $3 \times 5 \mathrm{~s}$ and centrifuged at $20,000 \times \mathrm{g}$ for $30 \mathrm{~min}$. Protein concentration was measured by Bradford assay using bovine serum albumin as the standard. The samples were stored at $-80^{\circ} \mathrm{C}$ until analysis.

\section{Two-Dimensional Gel Electrophoresis (2-DE)}

Two-DE was performed as previously described [23,24]. Briefly, five hundred micrograms of proteins were mixed with a rehydration solution (Bio-Rad, Hercules, CA) containing $7 \mathrm{M}$ urea, $2 \mathrm{M}$ thiourea, $4 \%$ CHAPS, $50 \mathrm{mM}$ DTT, $0.2 \%$ biolyte $3-10,0.1 \%$ biolyte $4-6$, and $0.1 \%$ biolyte 5-8 and a trace of bromophenol blue to a total volume of $300 \mu \mathrm{L}$. The mixtures were pipetted into IPG strip holder channels. After $14 \mathrm{~h}$ of rehydration, the strips, $\mathrm{pH} 3-10$ $\mathrm{NL}$, were transferred to the isoelectric focusing (IEF) holders (Bio-Rad, Hercules, CA). Prefocusing and focusing were performed on the IPGphor platfor (Bio-Rad, Hercules, CA) (500 V hold $2.5 \mathrm{~h}$, linear 500-1000 V increase $1 \mathrm{~h}, 1000 \mathrm{~V}$ hold $1 \mathrm{~h}$, linear 1000-8000 V increase $1.5 \mathrm{~h}$, and $8000 \mathrm{~V}$ hold $60,000 \mathrm{KV}$ h). Following IEF separation, the gel strips were equilibrated twice for $15 \mathrm{~min}$ each with equilibration buffer I and II (37.5 mM Tris-Cl, pH 8.8, 20\% glycerol, 2\% SDS, $6 \mathrm{M}$ urea, with 2\% DTT in buffer I and $2.5 \%$ iodoacetamide in buffer II, respectively). The equilibrated gel strips were then placed onto 8-16\% Tris $-\mathrm{HCl}$ gel, and sealed with $0.5 \%$ agarose in a Protean Plus Dodeca cell (Bio-Rad, Hercules, CA) until the bromophenol blue reached the bottom of the gels.

After 2-DE, the gels were stained with Pro-Q Diamond $[25,26]$. Then the gels were stained using SYPRO-Ruby (Molecular Probes, Eugene, OR) or visualized with the Coomassie Brilliant Blue R-250 (Merck, Germany) overnight at room temperature. Following 2-DE and protein staining, stained gels were scanned with a Pharox FX molecular imager (Bio-Rad) with a $532 \mathrm{~nm}$ laser 
excitation and a $580 \mathrm{~nm}$ band-pass emission filter. Spot detection, quantification and matching were identified using PDQuest 8.0 software (Bio-Rad). The intensity of each protein spot was normalized to the entire gel intensity of all spots detected. Quantitative analysis was performed using the Student's t-test. The confidence level was $95 \%$. Only those proteins of intensity difference $>2$-fold change were selected for MALDI-TOF /TOF MS.

\section{In-gel Trypsin digestion}

Protein spots of interest were excised from the gels and in-gel digested with trypsin as previously described [27]. Briefly, gel pieces were destained with $100 \mathrm{mM}$ ammonium bicarbonate in $30 \% \mathrm{ACN}$ and dried in a vacuum centrifuge. Ten ng of modified trypsin (Promega, Madison, WI) in $25 \mathrm{mM}$ ammonium bicarbonate was added, followed by incubation $20 \mathrm{~h}$ at $37^{\circ} \mathrm{C}$. The supernatant was collected, and then the peptides were further extracted three times from the gel pieces with $0.1 \%$ trifluoroacetic acid (TFA), 60\% ACN with vortexing for $45 \mathrm{~min}$ at room temperature. Peptides extracts were vacuum-dried.

\section{MALDI-TOF-MS}

For mass spectrometric analysis, the peptides extracts were brought up in $10 \mu \mathrm{L}$ of $0.1 \%$ TFA and cleaned using C18 ZipTip (Millippore, MA). Typically, $2 \mu \mathrm{L}$ of acyano-4-hydroxycinnamic acid (HCCA) matrix in 50\% ACN/0.1\% TFA was used to elute peptide onto the ground steel plate (Bruker, Germany). The internal standard from Bruker Bruker (MH1: angiotensin II, 1046.5420 Da; angiotensin I, 1296.6853 Da; substance P, 1347.7361 Da; bombesin, 1619.823 Da; ACTH clip 1839, $2465.199 \mathrm{Da})$ were used for mass scale calibration. The resulting peptides were extracted and analyzed by MALDI TOF/TOF mass spectrometer (Ultraflex III, Bruker, Germany) in the reflector mode and for sequence analysis in the "lift" mode.

\section{Protein identification and spectral data analysis}

The MS/MS spectrum from MALDI measurements were then searched against the Mus musculus subset (16235 sequences) of UniProt KB/Swiss-Prot/TrEMBL database (database version $57.15 ; 515203$ sequences) using the Mascot v 2.2 search program (Matrix Science, London, United Kingdom) (www.matrixscience.com). Search parameters for the database search with Mascot were set as follows: enzyme, trypsin; allowance of up to one missed cleavage peptide; fixed modification parameter, carbamidomethylation $(\mathrm{C})$; variable modification parameters, oxidation (at Met); mass tolerance for precursor ions was $\pm 1.2 \mathrm{Da}$; mass tolerance for fragment ions, $\pm 0.6 \mathrm{Da}$.
Mascot scores of proteins or peptides were used for protein identification $(\mathrm{p}<0.05)$. In the case of peptides matching to multiple members of a protein family, the positive identified protein was selected based on both the highest score and the highest number of matching peptides. These peaks were externally calibrated with peptide standards from Bruker (MH1: angiotensin II, 1046.5420 Da; angiotensin I, 1296.6853 Da; substance P, 1347.7361 Da; bombesin, $1619.823 \mathrm{Da}$; ACTH clip 1839, 2465.199 Da).

The synthesis rates of the differential proteins were calculated according to our in-house algorithms $[24,25]$. Oneway ANOVA with the Tukey's adjustment was used for multiple comparisons in SPSS 13.0 (SPSS Inc., Chicago, IL).

\section{Pathway analysis}

Ingenuity Pathway Analysis (IPA) (Ingenuity Systems, Inc., Redwood City, CA, www.ingenuity.com) was used for pathway, network and functional analyses of differential proteins in the present study.

\section{K-means clustering}

Protein ratios were transformed to the log scale (base 2) before clustering [28]. The Cluster 3.0 freeware software package was used for clustering analysis (http://bonsai.hgc.jp/ $\sim$ mdehoon/software/cluster/software.htm). Repeated (10100) K-means clustering of proteins was based on Pearson correlation coefficient of their expression profiles [29].

\section{Western blotting analysis}

Western blotting analysis was performed as described previously [29]. Briefly, after SDS-PAGE separation, proteins were then transferred to PVDF membranes (Millipore, CA) according to the manufacture's protocol, and antibody labeling was visualized using ECL reagent (Pierce Biotech Inc., Rockford, IL). Western blot score was a fraction of $\beta$-actin or $\beta$-tubulin, and measured in Quantity One (Bio-Rad).

To examine whether Annexin A1 is expressed in pancreatic cancer, we separately tested a set of serum samples from patients (pancreatic tumor; pT2/pT3) and healthy volunteer subjects with age-matched. The patient serum samples $(n=7)$ and the healthy volunteer blood samples $(n=12)$ were collected by City of Hope National Medical Center and NCI-designated Cancer Center (Duarte, CA) with proper informed consent according to a protocol approved by the Institute Review Board. All samples used in this study were further approved by the Institutional Review Board at Creighton University. The blood samples in BD Vacutainer ${ }^{\circledR}$ Blood Collection Tubes (BD Ventures, L.L.C., NJ) were fractionated by centrifuging at $1,000 \times \mathrm{g}$ for $10 \mathrm{~min}$. The serum samples were immediately divided into aliquots and frozen at $-80^{\circ} \mathrm{C}$. The mean $( \pm \mathrm{SD})$ age for the tumor 
patients was $61.3( \pm 8.1)$ years, and for the healthy volunteer group, $60.3( \pm 5.4)$ years. We measured serum levels of Annexin A1 by using Western blotting analysis. All the experiments were performed in triplicates.

\section{Results}

Oxythiamine caused protein expression in a dose-dependent manner

Using MTT assay, we determined the toxicity of OT to MIA PaCa-2 cells and found that the IC50 of OT for MIA PaCa-2 is $14.95 \mu \mathrm{M}$ (Additional file 1: Figure S1). To study whether OT caused protein expression in a dose-dependent fashion, MIA PaCa- 2 cells were treated with the stepwise concentrations of OT $(0 \mu \mathrm{M}, 5 \mu \mathrm{M}$, $50 \mu \mathrm{M}$ and $500 \mu \mathrm{M})$. Protein expression in MIA PaCa-2 cells was profiled using two-dimensional gel electrophoresis (2DE) (Figure 1A). From Figure 1A, we found that OT altered protein expression in a dose dependent manner. The differentially expressed proteins were selected using criterion of $>2$-fold difference among groups with statistical significance $(\mathrm{p}<0.05)$, and led to identification of eighteen proteins (Table 1). Among them, fourteen proteins were suppressed significantly, and four were induced remarkably, by OT treatment. Interestingly, heat shock cognate $71 \mathrm{kDa}$ protein was detected and identified from two adjacent spots in the gel (spots
$\# 2$ and \#3 in Figure 1A), suggesting that this protein may be underwent post-translational modification by OT treatment.

To further verify the expression patterns of these proteins in MIA cells, we selected alpha-enolase and 14-3-3 protein beta/alpha to examine protein expression by Western blot (Figure 1B). The level of alpha-enolase was increased by OT treatment, while expression of 14-3-3 protein beta/alpha was suppressed by OT at a stratified dose (Figure 1C). The results were in agreement with the 2-DE analyses.

\section{Oxythiamine altered dynamics of protein expression in MIA PaCa-2 cells}

To investigate whether OT treatment caused dynamic changes of cellular protein expression in MIA PaCa-2 cells, we treated MIA cells with OT at dose of $50 \mu \mathrm{M}$ in different time points $(0 \mathrm{~h}, 12 \mathrm{~h}$ and $48 \mathrm{~h})$. To detect functional cellular protein signals in MIA cells in response to OT treatment, we used ${ }^{15} \mathrm{~N}$ labeled amino acids as tracers to culture the cells, and dynamic synthesis rate of total proteins newly synthesized was calculated [24] (Figure 2A). Clearly, OT caused dynamic changes of total protein expression in time dependent fashion. A total of 46 proteins were identified (Table 2).
A

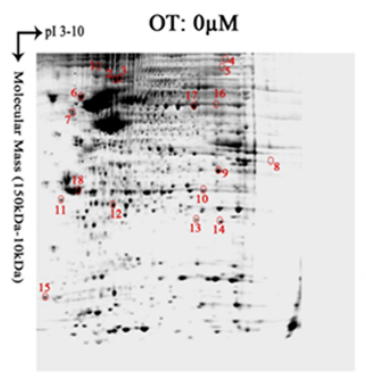

OT: $50 \mu \mathrm{M}$

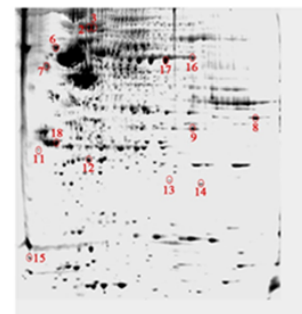

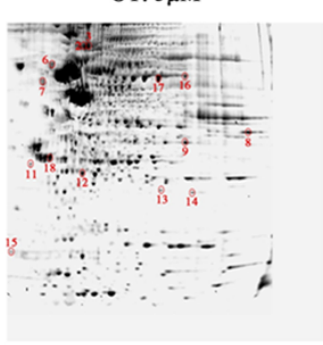

OT: $500 \mu \mathrm{M}$

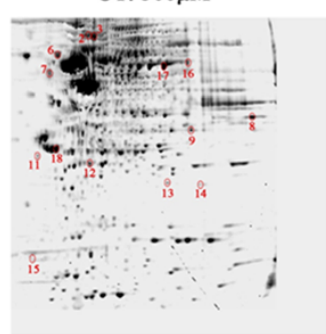

B

\section{OT ( 48 h)}

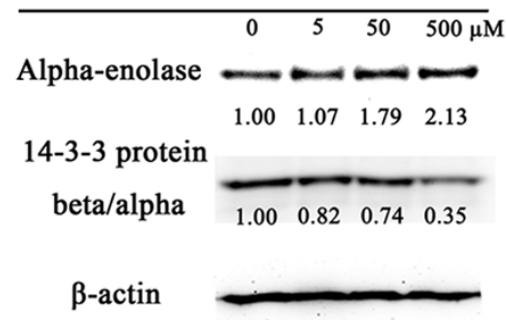

Figure 1 Dose-dependent analysis of the MIA PaCa-2 cells to oxythiamine. A. Two-DE patterns of whole-cell proteins obtained from MIA PaCa-2-2 cells treated with oxythiamine $(0 \mu \mathrm{M}, 5 \mu \mathrm{M}, 50 \mu \mathrm{M}$, and $500 \mu \mathrm{M})$. On the basis of PDQuest software analysis, ratios of normalized spot intensities of four different concentrations of oxythiamine were calculated, and spots showing more than 2.0-fold difference with statistical significance $(p<0.05)$ were selected after these 2D gels were stained by SYPRO Ruby. B. The validation of two differential proteins (alpha-enolase and 14-3-3 protein beta/alpha) for dose-dependent group. Western blot scores are annotated under the bands. The results were well consistent with the 2-DE analyses. 
Table 1 Identified proteins of differential expression of the MIA PaCa-2 cells in the OT-dose dependent group by MALDI-TOF/TOF MS

\begin{tabular}{|c|c|c|c|c|c|c|}
\hline \multirow[t]{2}{*}{ Spot No. ${ }^{a}$} & \multirow[t]{2}{*}{ Accession number ${ }^{b}$} & \multirow{2}{*}{ Protein name } & \multicolumn{4}{|c|}{ Ratio of OT-induced differential expression ${ }^{c}$} \\
\hline & & & 0 & 5 & 50 & $500(\mu \mathrm{M})$ \\
\hline 1 & P14625 & Endoplasmin & 1 & 0.27 & 0.33 & 0.20 \\
\hline 2 & P11142 & Heat shock cognate $71 \mathrm{kDa}$ protein & 1 & 0.41 & 025 & 0.19 \\
\hline 3 & P11142 & Heat shock cognate 71 kDa protein & 1 & 3.13 & 2.58 & 2.79 \\
\hline 4 & P13639 & Elongation factor 2 & 1 & 0.13 & 0.09 & 0.21 \\
\hline 5 & P08238 & Heat shock protein HSP 90-beta & 1 & 0.26 & 0.18 & 0.14 \\
\hline 6 & P07237 & Protein disulfide-isomerase & 1 & 0.07 & 0.22 & 0.09 \\
\hline 7 & P13489 & Ribonuclease inhibitor & 1 & 0.17 & 0.24 & 0.19 \\
\hline 8 & P22626 & Heterogeneous nuclear ribonucleoproteins A2/B1 & 1 & 7.51 & 11.45 & 10.96 \\
\hline 9 & P63244 & Guanine nucleotide-binding protein subunit beta-2-like 1 & 1 & 0.65 & 0.43 & 0.38 \\
\hline 10 & Q15056 & Eukaryotic translation initiation factor $4 \mathrm{H}$ & 1 & 0.32 & 0.15 & 0.27 \\
\hline 11 & P56537 & Eukaryotic translation initiation factor 6 & 1 & 0.40 & 0.24 & 0.17 \\
\hline 12 & P09211 & Glutathione S-transferase P & 1 & 0.61 & 0.57 & 0.26 \\
\hline 13 & P30086 & Phosphatidylethanolamine-binding protein 1 & 1 & 0.63 & 0.29 & 0.3 \\
\hline 14 & P62826 & GTP-binding nuclear protein Ran & 1 & 0.37 & 0.42 & 0.15 \\
\hline 15 & P60660 & Myosin light polypeptide 6 & 1 & 0.34 & 0.49 & 0.08 \\
\hline 16 & P51854 & Transketolase & 1 & 4.17 & 3.30 & 1.85 \\
\hline 17 & Q6GMP2 & Alpha-enolase & 1 & 0.89 & 2.13 & 2.29 \\
\hline 18 & P31946 & 14-3-3 protein beta/alpha & 1 & 0.76 & 0.50 & 0.55 \\
\hline
\end{tabular}

a. The numbers of the identified protein spots are indicated in Figures 1, 2 and 3;

b. Swiss-Prot/TrEMBL primary accession number.

c. The ratio of expression level (intensity on the gel) of each protein spot were calculated based on the control (0 $\mu \mathrm{M}$ OT) group.

On the basis of the time course study, the temporal expression patterns of OT-induced proteins were analyzed. Forty-five proteins identified from forty-six protein spots, which showed a 2-fold or greater change, revealed three different profile patterns, straight down-regulation (cluster $1,37 \%$ of total proteins), upright "V-shape" expression pattern (cluster 2, 47.8\% total), and downright "V-shape" pattern (cluster 3, 15.2\% total) (Figure 2B).

To further verify the expression patterns of these proteins in time dependent manner, four proteins were selected for further analyses by western blot (Figure 2C). The expression of peroxiredoxin- 6 and annexin A1 in cluster 1 were decreased upon the OT treatment. Calreticulin in cluster 3 was increased significantly at the $12 \mathrm{~h}$ time point, but significantly decreased to its basal level at the $48 \mathrm{~h}$ time point. Heterogeneous nuclear ribonucleoproteins $\mathrm{A} 2 / \mathrm{B} 1$ in cluster 2 showed an opposite trend to calreticulin (Figure 2C).

\section{OT suppressed phosphoprotein expression in MIA PaCa-2 cells}

Particularly, reversible phosphorylation of proteins plays a significant role that occurs in both prokaryotic and eukaryotic organisms, including cell apoptosis and differentiation, signal transduction, cell-cycle progression, energy storage and utilization [30-33]. To study whether cellular phosphor proteins were also altered by OT treatment, we analyzed phosphor protein expression in MIA cells (Figure 3). Obviously, OT suppressed expression of cellular phosphor proteins significantly. A total of 14 phosphorylated proteins were identified (Figure 3), and listed in Table 2. Of these 14 phosphorylated proteins, 6 proteins in Cluster 1 (heat shock cognate $71 \mathrm{kDa}$ protein, 14-3-3 protein epsilon, 14-3-3 protein beta/alpha, 14-3-3 protein zeta/ delta, eukaryotic translation initiation factor 6 and glutathione S-transferase P) showed concordant changes with total proteins, 6 proteins of Clusters 2 and 3 (nuclear autoantigenic sperm protein, stress-induced-phosphoprotein 1, alpha-enolase, eukaryotic translation initiation factor 3 subunit I, F-actin-capping protein subunit alpha-2 and tumor necrosis factor ligand superfamily member 13B) were discordant, and 2 (loss of heterozygosity 12 chromosomal region 1 protein and eukaryotic translation initiation factor 5A-1) were only observed in the phosphorylated patterns (Figure 3, Table 2). Decrease in phosphorylated proteins induced by OT treatment indicated that the inhibition of pentose phosphate pathway might cause a timedependent decrease of phosphorylated proteins patterns.

Functional annotation of the differential proteins identified To annotate the proteins identified in this study, all 52 differential proteins were analyzed with Ingenuity Pathway 


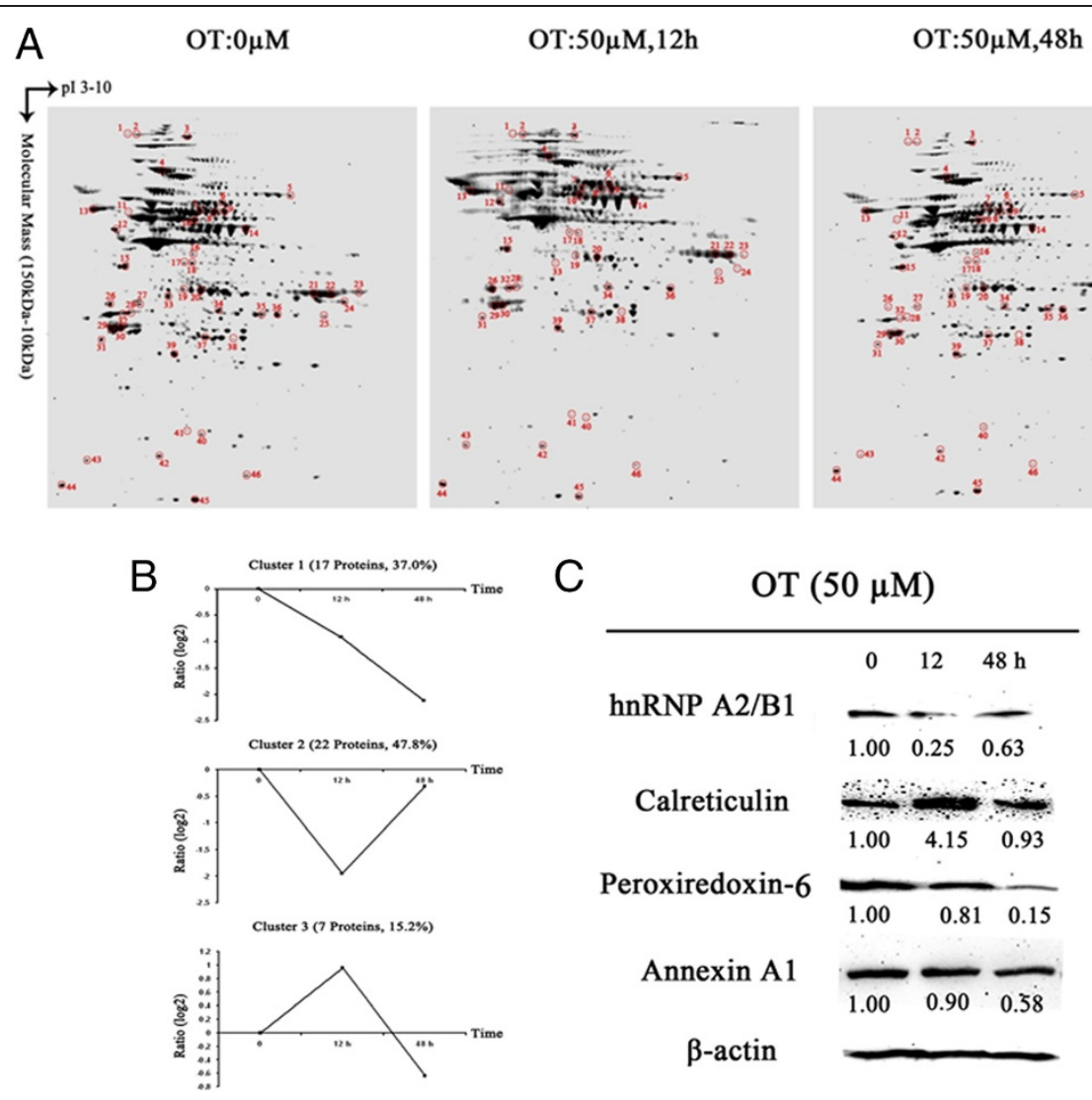

Figure 2 Time-dependent analysis of the MIA PaCa-2 cells to oxythiamine. A. Two-DE patterns of total proteins from the MIA PaCa-2 cells treated by OT with 0,12 and $48 \mathrm{~h}$. On the basis of PDQuest software analysis, ratios of normalized spot intensities of four different concentrations of oxythiamine were calculated, and spots showing more than 2.0-fold difference with statistical significance $(p<0.05)$ were selected after these 2D gels were stained with SYPRO Ruby. B. The temporal profile patterns of 45 differential proteins. The 0 min value was used as a basal time point to calculate the protein fold changes in $12 \mathrm{~h}$ and $48 \mathrm{~h}$. After transformed to the logarithmic scale (base 2), the temporal changed profiles of 45 differentially proteins were algorithmically subdivided into nine clusters using K-means clustering method. The protein number of each cluster is indicated. C. The validation of four differential proteins (peroxiredoxin-6, annexin A1, calreticulin and heterogeneous nuclear ribonucleoproteins A2/B1) for the time-dependent group. Western blot scores are annotated under the bands. The results were well consistent with the 2-DE analyses.

Analysis (IPA) (www.ingenuity.com). The potential functional annotation of these proteins revealed that most of the proteins were involved in signaling transduction of cell death, including cell death signaling $(29,37.7 \%)$, gene expression $(12,15.6 \%)$, post-translational modification (14, $18.2 \%)$, cell-to-cell interaction $(11,14.3 \%)$, protein folding (5, 6.5\%), and protein trafficking $(6,7.8 \%)$ (Figure 4A). Moreover, many proteins were involved in multiple signaling pathways that play role in incidence of diseases, including cancer $(28,24.3 \%)$, reproductive system disease $(17,14.8 \%)$, gastrointestinal disease $(12,10.4 \%)$, hematological disease $(12,10.4 \%)$, immunological disease (16, $13.9 \%)$, inflammatory disease $(19,16.5 \%)$, respiratory disease (11, 9.6\%) (Figure 4B).

The proteins quantitatively measured with turnover rate (a total of 36 proteins) were also annotated using IPA bioinformatics (Figure 4C). The differentially expressed proteins in three clusters are involved in multiple signaling pathways that are associated with tumor cell survival, and apoptosis. For examples, 14-3-3 proteins (14-3-3 protein epsilon, 14-33 protein beta/alpha and 14-3-3 protein zeta/delta) in cluster 1 , play roles in cell survival, cell proliferation, anti-apoptosis and anti-tumor suppression by activating ERK/MAPK signaling pathway and the mitochondrial apoptotic machinery [34-37]. Peroxiredoxin-2 and peroxiredoxin-4 in cluster 2, which were up-regulated in many cancers [38-40], showed a significant decrease upon OT-treatment for $12 \mathrm{hr}$ but increased to almost basal level after OT treatment for $48 \mathrm{hr}$. It suggested that these proteins in cluster 2 might be the early response molecules upon OT-treatment. Calreticulin in cluster 3, which is associated with proimmunogenic killing in cancer cells [41], was up-regulated upon OT-treatment for $12 \mathrm{hr}$ but then down-regulated to almost basal level after treatment for $48 \mathrm{hr}$, suggesting that OT-induced cell apoptosis might be associated with proimmunogenic killing in the early time. 
Table 2 Identified proteins of differential expression of the MIA PaCa-2 cells in the OT-time dependent group by MALDI-TOF/TOF MS

\begin{tabular}{|c|c|c|c|c|c|c|c|c|}
\hline \multirow{3}{*}{ Spot No. ${ }^{a}$} & \multirow{3}{*}{ Accession number ${ }^{b}$} & \multirow{3}{*}{ Protein name } & \multicolumn{6}{|c|}{ Ratio of OT-induced differential expression ${ }^{c}$} \\
\hline & & & \multicolumn{3}{|c|}{ Total proteins } & \multicolumn{3}{|c|}{ Phosphorylated proteins } \\
\hline & & & 0 & 24 & $48(h)$ & 0 & 24 & $48(h)$ \\
\hline 1 & $\mathrm{P} 49321^{\mathrm{e}}$ & Nuclear autoantigenic sperm protein & 1.00 & 0.37 & 1.35 & 1.00 & 0.09 & 0.05 \\
\hline 2 & $\mathrm{P} 14625^{\mathrm{f}}$ & Endoplasmin & 1.00 & 1.17 & 0.26 & - & - & - \\
\hline 3 & Q14697 ${ }^{\mathrm{e}}$ & Neutral alpha-glucosidase $A B$ & 1.00 & 0.41 & 0.89 & - & - & - \\
\hline 4 & $P 11142^{d}$ & Heat shock cognate $71 \mathrm{kDa}$ protein & 1.00 & 0.62 & 0.45 & 1.00 & 0.13 & 0.08 \\
\hline 5 & P29401 ${ }^{f}$ & Transketolase & 1.00 & 3.23 & 0.77 & - & - & - \\
\hline 6 & P31948 ${ }^{d}$ & Stress-induced-phosphoprotein 1 & 1.00 & 0.61 & 0.28 & 1.00 & 1.17 & 0.19 \\
\hline 7 & P30101 d & Protein disulfide-isomerase A3 & 1.00 & 0.30 & 0.06 & - & - & - \\
\hline 8 & P17987 ${ }^{d}$ & T-complex protein 1 subunit alpha & 1.00 & 0.39 & 0.21 & - & - & - \\
\hline 9 & P31146 ${ }^{e}$ & Coronin-1A & 1.00 & 0.45 & 0.74 & - & - & - \\
\hline 10 & P31943 ${ }^{d}$ & Heterogeneous nuclear ribonucleoprotein $\mathrm{H}$ & 1.00 & 0.88 & 0.49 & - & - & - \\
\hline 11 & $\mathrm{P} 07237^{\mathrm{e}}$ & Protein disulfide-isomerase & 1.00 & 0.37 & 0.84 & - & - & - \\
\hline 12 & P13489 ${ }^{d}$ & Ribonuclease inhibitor & 1.00 & 0.91 & 0.23 & - & - & - \\
\hline 13 & $\mathrm{P} 27797^{\mathrm{f}}$ & Calreticulin & 1.00 & 3.58 & 0.95 & - & - & - \\
\hline 14 & $P 06733^{f}$ & Alpha-enolase & 1.00 & 2.37 & 0.82 & 1.00 & 0.24 & 0.07 \\
\hline 15 & Q86VCo ${ }^{f}$ & 40 S ribosomal protein SA & 1.00 & 1.35 & 2.00 & - & - & - \\
\hline 16 & P52597 e & Heterogeneous nuclear ribonucleoprotein $\mathrm{F}$ & 1.00 & 0.31 & 0.73 & - & - & - \\
\hline 17 & P52907 e & F-actin-capping protein subunit alpha-1 & 1.00 & 0.49 & 0.81 & - & - & - \\
\hline 18 & O75821 e & Eukaryotic translation initiation factor 3 subunit I & 1.00 & 0.29 & 0.72 & 1.00 & 0.73 & 0.29 \\
\hline 19 & $\mathrm{P} 47755^{\mathrm{e}}$ & F-actin-capping protein subunit alpha-2 & 1.00 & 0.43 & 0.87 & 1.00 & 0.20 & 0.03 \\
\hline 20 & P04083 ${ }^{d}$ & Annexin A1 & 1.00 & 0.87 & 0.48 & - & - & - \\
\hline 21 & P04406 ${ }^{e}$ & Glyceraldehyde-3-phosphate dehydrogenase & 1.00 & 0.39 & 1.25 & - & - & - \\
\hline 22 & P04406 ${ }^{e}$ & Glyceraldehyde-3-phosphate dehydrogenase & 1.00 & 0.41 & 1.32 & - & - & - \\
\hline 23 & P09651 e & Heterogeneous nuclear ribonucleoprotein A1 & 1.00 & 0.17 & 1.39 & - & - & - \\
\hline 24 & P22626 ${ }^{e}$ & Heterogeneous nuclear ribonucleoproteins A2/B1 & 1.00 & 0.06 & 0.33 & - & - & - \\
\hline 25 & P52895 e & Aldo-keto reductase family 1 member $\mathrm{C} 2$ & 1.00 & 0.48 & 4.02 & - & - & - \\
\hline 26 & Q9BYE2 ${ }^{d}$ & Serine/threonine-protein kinase 13 & 1.00 & 0.11 & 0.07 & - & - & - \\
\hline 27 & P08758 ${ }^{d}$ & Annexin A5 & 1.00 & 0.43 & 0.36 & - & - & - \\
\hline 28 & Q9Y275 ${ }^{d}$ & 14-3-3 protein epsilon & 1.00 & 0.34 & 0.12 & 1.00 & 0.36 & 0.15 \\
\hline 29 & P31946 ${ }^{d}$ & 14-3-3 protein beta/alpha & 1.00 & 0.39 & 0.22 & 1.00 & 0.31 & 0.74 \\
\hline 30 & P63104 ${ }^{d}$ & 14-3-3 protein zeta/delta & 1.00 & 0.42 & 0.28 & 1.00 & 0.87 & 0.14 \\
\hline 31 & P56537 e & Eukaryotic translation initiation factor 6 & 1.00 & 0.39 & 0.47 & 1.00 & 0.76 & 0.41 \\
\hline 32 & $P 62258^{f}$ & Tumor necrosis factor ligand superfamily member $13 \mathrm{~B}$ & 1.00 & 2.13 & 0.29 & 1.00 & 0.33 & 0.17 \\
\hline 33 & Q6ZU15 ${ }^{\mathrm{e}}$ & Septin-14 & 1.00 & 0.04 & 0.78 & - & - & - \\
\hline 34 & Q13162 e & Peroxiredoxin-4 & 1.00 & 0.20 & 0.53 & - & - & - \\
\hline 35 & P18669 e & Phosphoglycerate mutase 1 & 1.00 & 0.08 & 2.59 & - & - & - \\
\hline 36 & P63244 ${ }^{e}$ & Guanine nucleotide-binding protein subunit beta-2-like 1 & 1.00 & 0.49 & 0.91 & - & - & - \\
\hline 37 & P04792 ${ }^{d}$ & Heat shock protein beta-1 & 1.00 & 0.43 & 0.28 & - & - & - \\
\hline 38 & P30041 d & Peroxiredoxin-6 & 1.00 & 0.89 & 0.37 & - & - & - \\
\hline 39 & P09211 d & Glutathione S-transferase P & 1.00 & 0.77 & 0.42 & 1.00 & 0.26 & 0.04 \\
\hline 40 & P16949 e & Stathmin & 1.00 & 0.35 & 0.46 & - & - & - \\
\hline 41 & P15531 d & Nucleoside diphosphate kinase A & 1.00 & 0.97 & 0.09 & - & - & - \\
\hline 42 & P32119 e & Peroxiredoxin-2 & 1.00 & 0.37 & 0.49 & - & - & - \\
\hline 43 & $P 60660^{d}$ & Myosin light polypeptide 6 & 1.00 & 0.88 & 0.23 & - & - & - \\
\hline
\end{tabular}


Table 2 Identified proteins of differential expression of the MIA PaCa-2 cells in the OT-time dependent group by MALDI-TOF/TOF MS (Continued)

\begin{tabular}{lccccccc}
\hline 44 & Q8N1F1 $^{f}$ & Putative uncharacterized protein NCRNA00188 & 1.00 & 1.15 & 0.50 & - & - \\
45 & P05109 & Protein S100-A8 & 1.00 & 0.29 & 0.73 & - & - \\
46 & P62937 & Peptidyl-prolyl cis-trans isomerase A & 1.00 & 0.07 & 0.19 & - & - \\
47 & Q969J3 & Loss of heterozygosity 12 chromosomal region 1 protein & - & - & - & - \\
48 & P63241 & Eukaryotic translation initiation factor 5A-1 & - & - & - & 0.00 & 0.02 \\
\hline
\end{tabular}

a. The numbers of the identified protein spots are indicated in Figures 1, 2, and 3;

b. Swiss-Prot/TrEMBL primary accession number.

c. The ratio of expression level (intensity on the gel) of each protein spot were calculated based on the control (0 $\mu \mathrm{M}$ OT) group.

d. Protein expression in Cluster 1.

e. Protein expression in Cluster 2.

f. Protein expression in Cluster 3.

\section{OT interrupted the protein synthesis rate}

Dynamic protein synthesis, which is the results of protein synthesis and degradation, is the key to regulate the cell signaling and determine the cell destiny [42,43]. In our study, dynamic protein synthesis rates of differential proteins were able to be determined by our recently developed method [24]. A total of 41 proteins were measured, including 7 proteins with a turnover rate $<45 \%$ (protein disulfide-isomerase A3, alpha-enolase, tumor necrosis factor ligand superfamily member $13 \mathrm{~B}$, eukaryotic translation initiation factor 6 , nucleoside diphosphate kinase $\mathrm{A}, \mathrm{my}$ osin light polypeptide 6 and phosphoglycerate mutase 1), 5 proteins with a turnover rate $>65 \%$ (heterogeneous nuclear ribonucleoproteins A2/B1, peroxiredoxin-2, peroxiredoxin6 , endoplasmin and nuclear autoantigenic sperm protein) and other 29 proteins with a turnover rate between $45 \%$ and 65\% (Table 3). Proteins with high protein turnover rate indicated they may be actively involved in some cell physiological processes, especially in drug treatment cells.

We also examined the time-dependent relationship of protein synthesis to OT treatment in MIA PaCa cells (Table 3). Because of the low protein concentration recovered from the 2-D gel, we were only able to determine the fraction of new synthesis in eight proteins at the various time points of OT treatment. Table 3 shows the time response of the fraction of new synthesis (\% new synthesis in 12 and 48 hours) of eight proteins. There were no significant mass shifts of the peptide spectra at $12 \mathrm{~h}$ time point of OT treatment. It indicated that there may be no the new syntheses of proteins before $12 \mathrm{~h}$. Fraction of new syntheses of five proteins were decreased, three were increased at $48 \mathrm{~h}$ time point of OT treatment. It suggested the differential effects of OT treatment on protein turnover of the eight proteins.

The effect of ${ }^{15} \mathrm{~N}$ incorporation on the isotopomer distribution of a peptide from protein spot \#20 is illustrated in Figure 5. The isotopomer distribution of fragment $1702.5 \mathrm{~m} / \mathrm{z}$ in spot \#20 (Annexin A1) is shown in Figure 5A-F. The distribution of the unlabeled fragment $\left({ }^{14} \mathrm{~N}\right)$ is showed in Figure 5A.

The same peptide, labeled with ${ }^{15} \mathrm{~N}$ enriched medium and treated with or without $50 \mu \mathrm{M}$ OT for $12 \mathrm{~h}$, is illustrated in Figure 5B,C. There were no significant differences between the three spectra. It indicated protein synthesis was not interrupted at the $12 \mathrm{~h}$ time point of OT treatment in the MIA PaCa-2 cells. Figure 5D shows the spectrum from cells grown in $50 \%{ }^{15} \mathrm{~N}$ enriched medium for $48 \mathrm{~h}$. It suggested the obvious spectrum shift in mass comparing with ${ }^{14} \mathrm{~N}$ labeled spectrum. The spectrum in Figure 5E is from the cells grown in ${ }^{15} \mathrm{~N}$ enriched medium and $50 \mu \mathrm{M}$ OT for $48 \mathrm{~h}$, which showed smaller mass shift than that of only $50 \%{ }^{15} \mathrm{~N}$

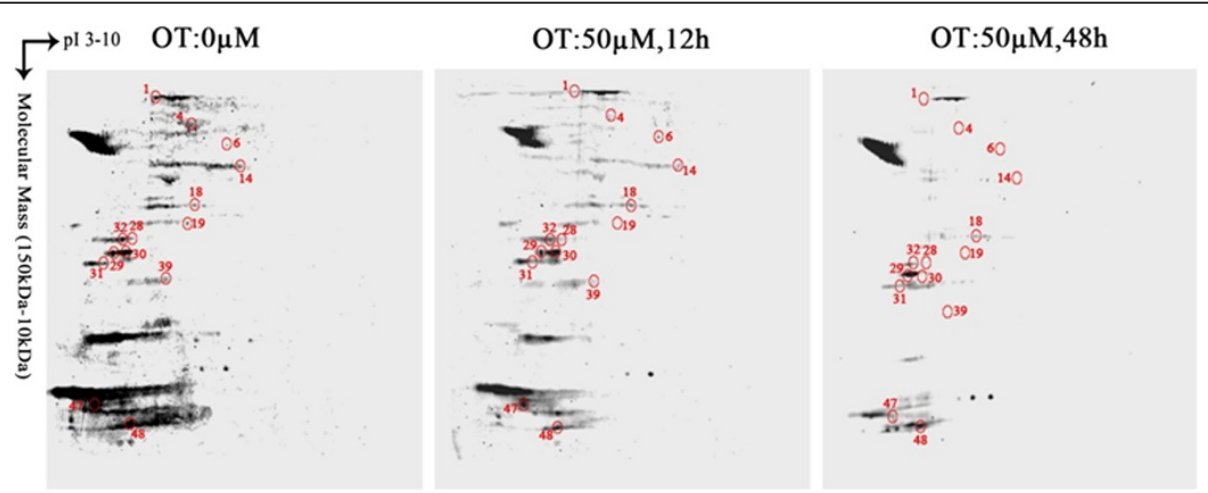

Figure 3 Two-DE patterns of phosphorylated proteins from the MIA PaCa-2 cells treated by OT with 0,12 and $48 \mathrm{~h}$. 

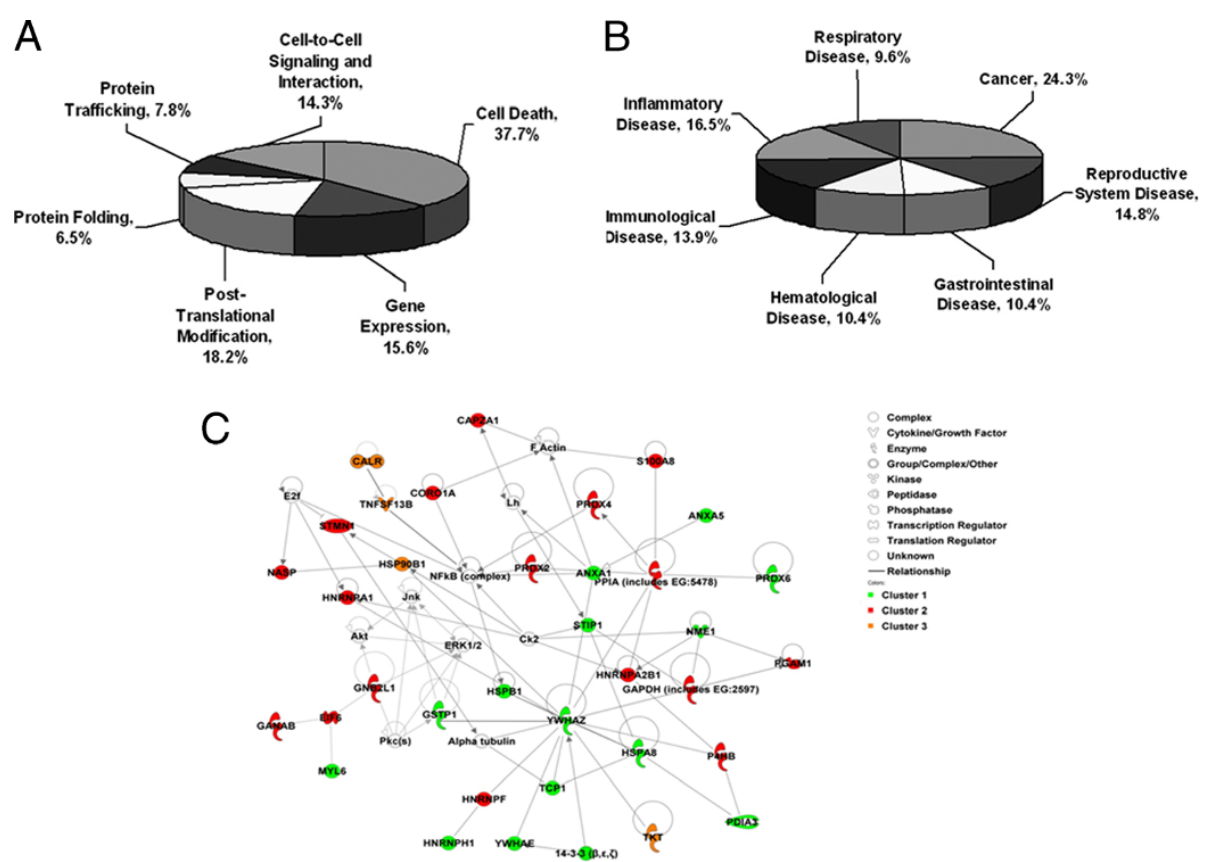

Figure 4 Functional characteristics of the differential proteins identified. A. Functional analysis of fifty-two differential proteins via Ingenuity database (www.ingenuity.com). Molecular functional annotation including cell death (29, 37.7\%), gene expression (12, 15.6\%), post-translational modification (14, 18.2\%), cell-to-cell signaling and interaction (11, 14.3\%), protein folding (5, 6.5\%), protein trafficking $(6,7.8 \%)$. B. Classification related with diseases and disorders including cancer $(28,24.3 \%)$, reproductive system disease (17, 14.8\%), gastrointestinal disease (12, 10.4\%), hematological disease $(12,10.4 \%)$, immunological disease (16, 13.9\%), inflammatory disease (19, 16.5\%), respiratory disease (11, 9.6\%). C. The analysis of network based on the Ingenuity database. A total of 36 differential proteins, which showed three different profiles response to OT treatment, were matched in the signaling network of cancer and cell death.

enrichment. Turnover rates were then calculated by multiple linear regression analysis of the observed peptide spectrum. The fraction of new synthesis of the peptide was reduced from $55 \%$ to $37 \%$ by OT treatment. Using a Mascot database search, we determined that the sequence of the peptide is part of a protein annexin A1
(Figure 5F). It suggested that OT could inhibit the synthesis of annexin A1.

\section{Expression of Annexin A1 in human pancreatic cancer}

Annexin A1, a major substrate for epidermal growth factor receptor kinase, plays an important role in cancer

Table 3 OT interrupted the protein synthesis rates

\begin{tabular}{|c|c|c|c|}
\hline \multirow{3}{*}{ Protein name } & \multicolumn{3}{|c|}{ Protein synthesis rate } \\
\hline & \multirow[t]{2}{*}{$48\left({ }^{15} \mathrm{~N} \text { only }\right)^{\mathrm{g}}$} & \multicolumn{2}{|c|}{$50 \mu \mathrm{M}$ OT (h) } \\
\hline & & $12^{\mathrm{h}}$ & $48^{i}$ \\
\hline Endoplasmin & $71 \%$ & $-^{j}$ & $42 \%$ \\
\hline Heat shock cognate $71 \mathrm{kDa}$ protein & $65 \%$ & - & $52 \%$ \\
\hline Ribonuclease inhibitor & $59 \%$ & - & $36 \%$ \\
\hline Annexin A1 & $55 \%$ & - & $37 \%$ \\
\hline Glyceraldehyde-3-phosphate dehydrogenase & $61 \%$ & - & $70 \%$ \\
\hline Heterogeneous nuclear ribonucleoprotein F & $63 \%$ & - & $78 \%$ \\
\hline Heterogeneous nuclear ribonucleoproteins A2/B1 & $67 \%$ & - & $45 \%$ \\
\hline Peroxiredoxin-4 & $65 \%$ & - & $73 \%$ \\
\hline Peroxiredoxin-6 & $70 \%$ & - & $52 \%$ \\
\hline
\end{tabular}

g. Protein turnover rates were measured from cells treated with ${ }^{15} \mathrm{~N}$ enriched medium for $48 \mathrm{~h}$ without OT treatment.

h. Protein turnover rates were measured from cells treated with ${ }^{15} \mathrm{~N}$ enriched medium and $50 \mu \mathrm{M}$ OT for $12 \mathrm{~h}$.

i. Protein turnover rates were measured from cells treated with ${ }^{15} \mathrm{~N}$ enriched medium and $50 \mu \mathrm{M}$ OT for $48 \mathrm{~h}$.

j. "-" means no significant changes of protein turnover rates compare to basal group (0 hr). 


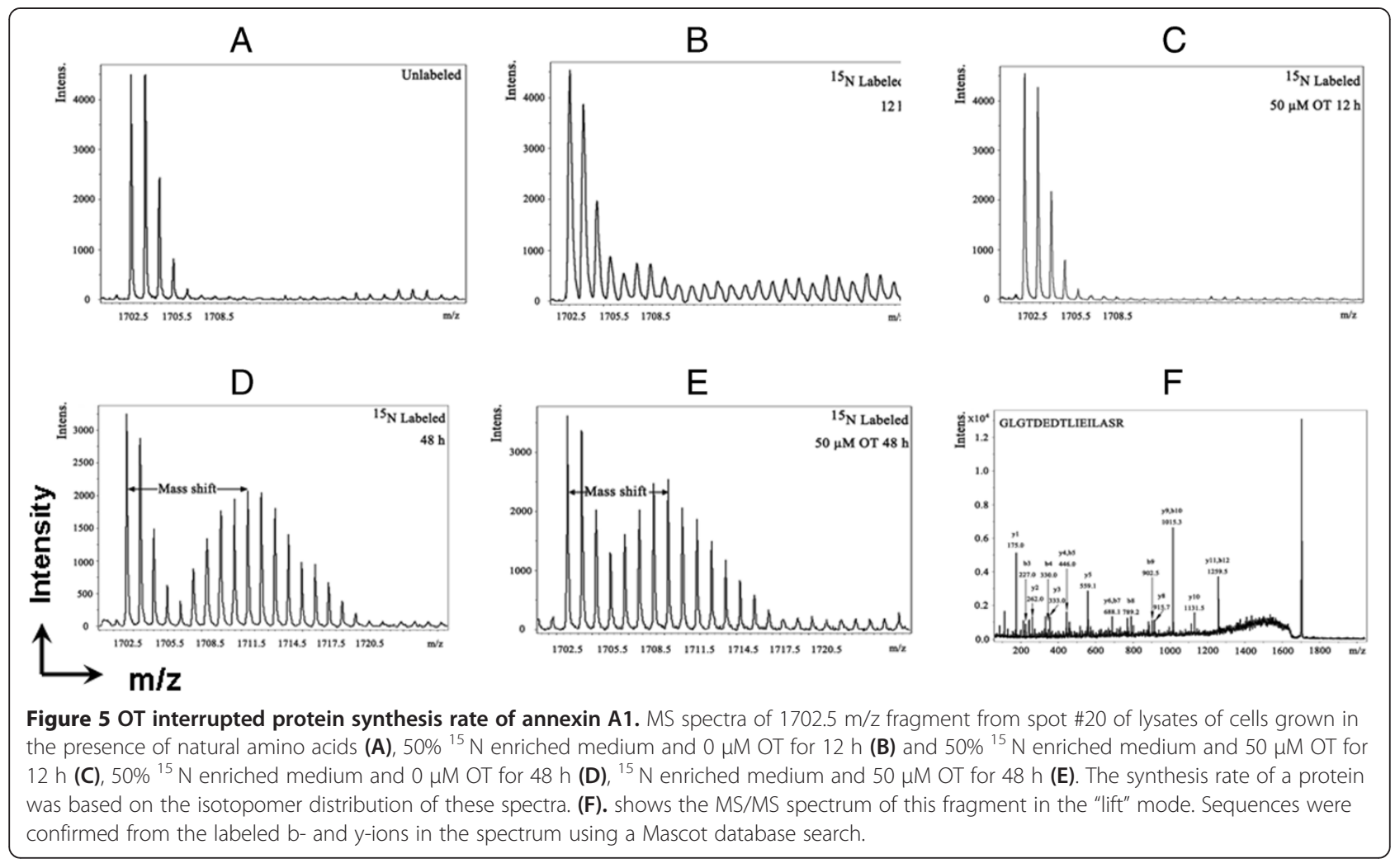

development and progression [44,45]. Although expression of Annexin A1 was reported to be associated with a number of cancers including pancreatic cancer [46], the molecular mechanism underlying is unknown. To further validate the expression of Annexin A1 in patients with pancreatic cancer, Western blot analysis was performed in archived clinic plasma samples from patients who had pancreatic cancer $(\mathrm{n}=7)$ and healthy control $(n=7)$ (Figure 6A/B). Clearly, Annexin A1 is expressed significantly in pancreatic cancer patients compared to the healthy controls $(\mathrm{p}<0.05)$ (Figure 6B). These results agreed well with our in vitro study above, suggesting that Annexin A1 may be developed as a surrogated marker potentially useful for early detection of pancreatic cancer.

\section{Discussion}

Cancer cells utilize glucose maximally as a main source of energy supply and substrates for proliferation through glycolytic metabolic pathways [1,2]. Inhibition of the activity of the key enzymes (e.g., transketolase/transadolase) in these metabolic networks, resulting in significant limitation of glucose utilization, provides an ideal strategy for an effective therapy of cancer. A number of our previous studies have shown that inhibition of activity of either transketolase in the pentose phosphate cycle, or glycogen phosphorylase causes cell cycle arrest leading to cancer cell apoptosis $[17,23,47,48]$. In this study, we found that transketolase inhibitor OT altered dynamics of cellular protein expression in MIA $\mathrm{PaCa}-2$ cells by interrupting the rates of protein de novo synthesis. This study provides 1) an important clinical implication for identifying novel cellular protein signals/targets that are associated

A

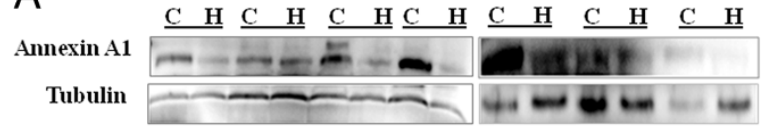

B

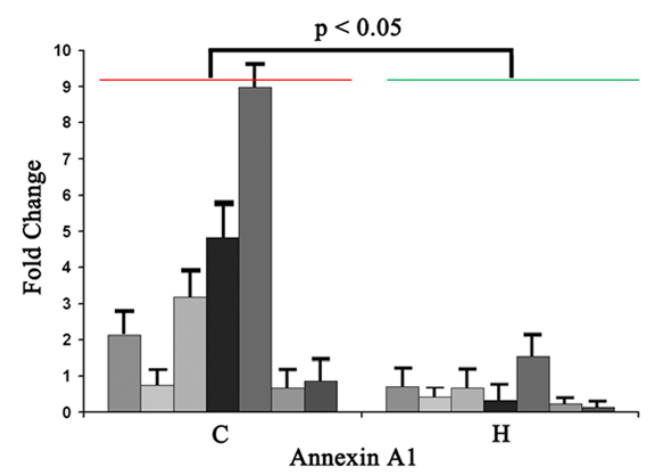

Figure 6 Differantial expression of annexin A1 in pancreatic cancer and healthy plasma. A. Western blot of seven random pairs of human plasma from pancreatic cancer and healthy people. B. Statistical analysis of the Western blot in the Panel A. Band intensity was normalized to that of tubulin. C, plasma from pancreatic cancer patiant; $H$, palsma from healthy people. 
mechanistically with cancer treatment; 2) a novel approach for detecting signal molecules that initiate drug resistance.

Small molecule antimetabolites are among the more effective chemotherapeutic agents in use today. Currently, gemcitabine, 5-fluorouracil (5-FU), and imatinib, are commonly used for the treatment of pancreatic cancer [49-51]. However, the response rate to either gemcitabine, or imatinib, and patient survival, are poor $[52,53]$. There is an urgent need to discover additional chemotherapeutic targets such as metabolic enzymes that play a crucial role in controlling the growth of cancer cells. In this study, we found that OT caused protein expression in a time dependent fashion. Peroxiredoxin- 6 of cluster 1 , which can suppress TRAIL-mediated cell death in human cancer cells by binding to death effector domain caspase [54], was constantly down-regulated by the duration of OT treatment (from $0 \mathrm{hr}$ to $48 \mathrm{hrs}$ ) (Figure 2B). It implicated that OT induced cell death by hperoxiredoxin- 6 related TRAIL-induced pathway. However, peroxiredoxin-2 and peroxiredoxin- 4 of cluster 2 , the same ubiquitous family of peroxiredoxin-6, which were up-regulated in many cancers [38-40], were shown in an upright "V" shape (Figure 2B). It suggested that the two proteins might be the only early response molecules upon OT-treatment comparing with peroxiredoxin-6. Calreticulin of cluster 3 was shown in a downright "V" shape (Figure 2B). It suggested calreticulin might have an opposite function of OTinduced cell apoptosis as the early time response molecular comparing with peroxiredoxin-2 and peroxiredoxin-4. The protein expression pattern in three clusters suggested that metabolic dynamic changes (dynamic changes of transketolase activity) in MIA cancer cells in response to OT treatment caused dynamic changes of cellular protein signals. Protein expression pattern indicates that dynamics of these protein expressions differs in MIA cells in response to OT treatment. Interestingly, expression of these proteins in cluster 2 and 3 was no significant difference in MIA cells treated with OT for $48 \mathrm{hrs}$, but significantly changed in MIA cells treated with OT for $12 \mathrm{hrs,} \mathrm{com-}$ pared to that in MIA cells at basal line ( 0 hrs $)$. Early response proteins (e.g., Glyceraldehyde-3-phosphate dehydrogenase, S100A8) in clusters 2 and 3 may play an important role in MIA cells against OT treatment. Several studies revealed that expression of both Glyceraldehyde-3phosphate dehydrogenase and S100A8 are suppressed in Raw264.7 cells [25,26,55] or bone cells [56,57] in response to toxins or tobacco smoke, suggesting that these proteins play an important role in cell defense (survival). Suppression of the protein expression may be part of cell emergent response mechanism since OT treatment cut off supplies of substrates and energy for cancer cell proliferation.

Because of a wild range of protein concentration in cells, it is the most difficult to study in a truly comprehensive manner. Standard proteomics usually compares amounts of proteins in cells in two different states (e.g. disease vs. normal) or conditions (e.g. treatment vs. non treatment) [58]; it does not address the dynamics of the proteome in the different biological states that are being compared, nor does it provide information about the mechanisms whereby the system changes from one state to the other. Thus, data obtained from this study may provide unique cell survival mechanism.

Previous study showed that dynamic changes of metabolic enzyme activity determined the metabolic sensitivity of cancer cells to the treatment [47], therefore, the early responsive protein signals upon OT treatment may be indicatives for the sensitivity of pancreatic cancer cells to the treatment in molecular level.

The dynamic changes of the cellular molecules (mRNAs, proteins, and metabolites) depend upon the physiological, developmental, or pathological state of living cells [59]. A change in the proteome may be the most important outcomes of a cellular response, such as autophagy, to exogenous stimuli. Autophagy is a constitutive, catabolic process leading to the lysosomal degradation of cytosolic proteins and organelles. Dynamic changes of proteins identified in Clusters 3 and 4 may reflect the cellular autophaging phenomena.

Because of a wild range of protein concentration in cells, it is the most difficult to study changes of protein expression in a truly comprehensive manner. Standard proteomics usually compares amounts of proteins in cells in two different states (e.g. disease vs. normal) or conditions (e.g. treatment $v s$. non treatment) [58]; it does not address the dynamics of the proteome in the different biological states that are being compared, nor does it provide information about the mechanisms whereby the system changes from one state to the other. This study provides more dynamic information of cellular protein signals than our previous studies and others [23], which some dynamic information of proteins in clusters 2 and 3 may be missed (or so-called "false negative" errors) when standard proteomics approach is used in our previous studies.

Protein turnover is the balance between protein synthesis and protein degradation (or breakdown), which is believed to decrease with age in all senescence organisms including humans. This results in an increase in the amount of damaged protein within the body. It is unknown if this is a cause or consequence of aging but it seems likely that it is in fact both. The damaged protein results in a slower protein turnover which then results in more damaged protein causing an exponential increase in damage to all protein within the body and to aging. Protein turnover is being considered as a missing dimension in proteomics for biomedical research [59]. The dynamics of protein turnover is one of key features to the understanding of regulation of protein expression 
and protein-protein interaction in cells [24,60]. The level of expression of a protein depends on the rates of its synthesis and degradation. Thus the turnover of a protein is an important indicator of its functional significance in cells. Despite its evident importance, the role of protein turnover has not previously been considered in analyses of the proteome. Protein turnover can be quantified on a protein-by-protein basis. With the established method [24], in this study we were able to quantitatively measure the rates of newly synthesized proteins. Among 41 proteins measured, 7 proteins are with a turnover rate of $<45 \%, 5$ proteins are with a turnover rate of $>65 \%$, and 29 proteins are with a turnover rate between $45 \%$ and $65 \%$. The turnover rates of the proteins with extreme high or low levels are related to specific status of cell physiology (e.g., suppression of metabolic signaling).

Intriguingly, we did not observe de novo synthesized peptides in MIA cells treated with OT in $12 \mathrm{~h}$. This is reasonable since it takes more than $24 \mathrm{hr}$ for a specific gene translating to the cognate protein. The explanation for detection of the differential expressed proteins at 12 -h treatment may be 1 ) because OT directly or indirectly activated pathways of degradation resulting in rapid degradation of cellular functional proteins; 2) because OT directly or indirectly turned on pathways of posttranslational modification leading to the increased amount of proteins. This notion can be demonstrated from Figure $6 \mathrm{~B} / \mathrm{C}$, obviously, de novo synthesis of proteins cannot be detected.

Previous study revealed that some active metabolic pathways, TCA, glycolysis, oxidative phosphorylation and the pentose phosphate pathway, were interconnected with the critical signaling pathways in proliferating cells [61]. Inhibiting of these metabolic pathways could affect the biological macromolecular synthesis and suppress cell proliferation [23,47]. In previous studies it had been shown OT could cause the inhibition of nucleic acid synthesis metabolic through increasing imbalances in pentose phosphate cycle [18]. In our study, the expression profile patterns of cellular phosphorylated proteins of MIA PaCa2 were significantly inhibited by OT treatment (Figure 3). This phenomenon might be caused by inhibition of biological macromolecular synthesis or some critical signaling pathways related phosphorylation.

Certainly, this is a principal proof study examining whether interference of the interactive metabolic and cell signaling pathways alters expression of protein signals associated with cellular abnormal activity of protein turnover. Although information obtained in a single pancreatic cancer cell line MIA PaCa-2 may be limited to a study in other cell lines, protein signals identified in this study may provide useful information for further development of novel biomarkers and/or drug targets for administration of pancreatic cancer.

\section{Conclusion}

This study revealed that inhibition of single metabolic enzyme transketolase by OT altered dynamics of cellular protein expression by interfering rates of de novo protein synthesis in MIA PaCa-2 pancreatic cancer cells. These cellular dynamic protein signals may be involved in several signaling pathways of cell apoptosis. These results may help understand better molecular mechanism of the anti-tumor activity of OT.

\section{Additional file}

Additional file 1: Figure S1. The effects of OT on MIA PaCa-2-2 cel proliferation using MTT assay. OT could cause the inhibition of cell growth and induce cell apoptosis on MIA PaCa-2 cell in a dose-dependent manner. IC50 of OT for MIA PaCa-2-2 cells was $14.95 \mu \mathrm{M}$.

\section{Abbreviations}

2-DE: Two-dimensional electrophoresis; MALDI: Matrix assisted laser desorption ionization; TOF/TOF MS: Time-of-flight/time-of-flight mass spectrometry; PMF: Peptide mass fingerprinting; OT: Oxythiamine; TK: Transketolase.

\section{Competing interests}

The authors declare that they have no competing interests.

\section{Authors' contributions}

JW and DM, carried out rat experiments. DM, drafted the manuscript. GGX were heavily involved in experimental design, and also mainly involved in scientific correction of the draft manuscript. JX, $Y Z$, and $X Z$ were involved in sample collection and measurements of proteins, WNL, VLG, QW, YY, and RR, were involved in project discussion. All authors were involved in drafting the manuscript and revising it for critically important content. All authors have read and approved the final manuscript.

\section{Acknowledgements}

This work is fully supported by grants awarded to Dr. Gary Guishan Xiao (GGX) from the Bone Biology Program of the Cancer and Smoking Related Disease Research Program and the Nebraska Tobacco Settlement Biomedical Research Program (LB692, LB595, and LB506).

\section{Author details}

${ }^{1}$ Genomics \& Functional Proteomics Laboratories, Osteoporosis Research Center, Creighton University Medical Center, 601 N 30th ST, Suite 6730, Omaha, NE 68131, USA. ${ }^{2}$ Metabolomics Core, UCLA Center of Excellence in Pancreatic Diseases, Harbor-UCLA Medical Center, Torrance, CA 90502, USA. ${ }^{3}$ Department of Respiratory Medicine, Dalian Medical University, Dalian 116027, China. ${ }^{4}$ Molecular Clinical Pharmacology, City of Hope Cancer Center, Duarte, CA 90101, USA. ${ }^{5}$ Department of Respiratory Medicine, The Fifth Hospital of Dalian, Dalian 116027, China. ${ }^{6}$ The Medical College of Dalian University, Dalian Economic \& Technological Development Zone, Dalian 116622, China

Received: 13 June 2013 Accepted: 23 July 2013

Published: 27 July 2013

\section{References}

1. Crabtree HG: Observations on the carbohydrate metabolism of tumours. Biochem J 1929, 23:3

2. Warburg $\mathrm{OH}$ : On the origin of cancer cells. Science 1956, 123:3191.

3. Straussand LG, Conti PS: The applications of PET in clinical oncology. J Nucl Med 1991, 32:4.

4. Lavayssièreemail R, Cabée AE, Filmont JE: Clinical applications of PET in oncology. Radiology 2004, 231:2.

5. Maher JC, Krishan A, Lampidis TJ: Greater cell cycle inhibition and cytotoxicity induced by 2-deoxy-D-glucose in tumor cells treated under hypoxic vs aerobic conditions. Cancer Chemother Pharmacol 2004, 53:2. 
6. Floridi A, Bruno T, Miccadei S, Fanciulli M, Federico A, Paggi MG: Enhancement of doxorubicin content by the antitumor drug lonidamine in resistant Ehrlich ascites tumor cells through modulation of energy metabolism. Biochem Pharmacol 1998, 56:7.

7. Floridi A, Paggi MG, D'Atri S, De Martino C, Marcante ML, Silvestrini B, Caputo A: Effect of lonidamine on the energy metabolism of Ehrlich ascites tumor cells. Cancer Res 1981, 41:4661.

8. Xu RH, Pelicano H, Zhou Y, Carew JS, Feng L, Bhalla KN, Keating MJ, Huang $P$ : Inhibition of glycolysis in cancer cells: a novel strategy to overcome drug resistance associated with mitochondrial respiratory defect and hypoxia. Cancer Res 2005, 65:2.

9. Ko YH, Pedersenemai PL, Geschwind JF: Glucose catabolism in the rabbit VX2 tumor model for liver cancer: characterization and targeting hexokinase. Cancer Lett 2001, 173:1.

10. Geschwind JF, Georgiades CS, Ko YH, Pedersen P: Recently elucidated energy catabolism pathways provide opportunities for novel treatments in hepatocellular carcinoma. Expert Rev Anticancer Ther 2004, 4:3.

11. Boren J, Cascante M, Marin S, Comín-Anduix B, Centelles JJ, Lim S, Bassilian S, Ahmed S, Lee WNP, Boros LG: Gleevec (STI571) influences metabolic enzyme activities and glucose carbon flow toward nucleic acid and fatty acid synthesis in myeloid tumor cells. J Biol Chem 2001, 276:41.

12. Gottschalk S, Anderson N, Hainz C, Eckhardt SG, Serkova NJ: Imatinib (STI571)-mediated changes in glucose metabolism in human leukemia BCR-ABL-positive cells. Clin Cancer Res 2004, 10:19

13. Serkova NJ, Boros LG: Detection of resistance to imatinib by metabolic profiling: clinical and drug development implications. Am J Pharmacogenomics 2005, 5:5.

14. Raïs $B$, Comin B, Puigjaner J, Brandes JL, Creppy E, Saboureau D, Ennamany $R$, Lee WNP, Boros LG, Cascanteemal M: Oxythiamine and dehydroepiandrosterone induce a G1 phase cycle arrest in Ehrlich's tumor cells through inhibition of the pentose cycle. FEBS Lett 1999, 456:1.

15. Comín-Anduix B, Boren J, Martinez S, Moro C, Centelles JJ, Trebukhina R, Petushok N, Lee WNP, Boros LG, Cascante M: The effect of thiamine supplementation on tumour proliferation. A metabolic control analysis study. Eur J Biochem 2001, 268:15.

16. Pelicano H, Martin DS, Malt, Xu R-H, Huang P: Glycolysis inhibition for anticancer treatment. Oncogene 2006, 25:34.

17. Boros LG, Puigjaner J, Cascante M, Lee WNP, Brandes JL, Bassiian S, Yusuf F, Williams RD, Muscarella P, Melvin WS, Schirmer WJ: Oxythiamine and dehydroepiandrosterone inhibit the nonoxidative synthesis of ribose and tumor cell proliferation. Cancer Res 1997, 57:19.

18. Ramos-Montoya A, Lee WNP, Bassilian S, Lim S, Trebukhina RV, Kazhyna MV, Ciudad CJ, Noé V, Centelles JJ, Cascante M: Pentose phosphate cycle oxidative and nonoxidative balance: A new vulnerable target for overcoming drug resistance in cancer. Int J Cancer 2006, 119:12.

19. Moreno-Sánchez R, Rodríguez-Enríquez S, Marín-Hernández A, Saavedra E: Energy metabolism in tumor cells. FEBS J 2007, 274:6.

20. Rodríguez-Enríquez S, Vital-González PA, Flores-Rodríguez FL, MarínHernández A, Ruiz-Azuara L, Moreno-Sánchez R: Control of cellular proliferation by modulation of oxidative phosphorylation in human and rodent fast-growing tumor cells. Toxicol Appl Pharmacol 2006, 215:2.

21. Romijn JC, Verkoelen CF, Schroeder FH: Application of the MTT assay to human prostate cancer cell lines in vitro: establishment of test conditions and assessment of hormone-stimulated growth and druginduced cytostatic and cytotoxic effects. Prostate 1988, 12:1.

22. Mosmann T: Rapid colorimetric assay for cellular growth and survival: application to proliferation and cytotoxicity assays. J Immunol Methods 1983, 65:1-2.

23. Zhang H, Cao R, Lee WN, Deng C, Zhao Y, Lappe J, Recker R, Yen Y, Wang Q, Tsai M, Go VL, Xiao GG: Inhibition of protein phosphorylation in MIA pancreatic cancer cells: confluence of metabolic and signaling pathways. J Proteome Res 2010, 9:2.

24. Zhao Y, Lee WN, Lim S, Go VL, Xiao J, Cao R, Zhang H, Recker RR, Xiao GG: Quantitative proteomics: measuring protein synthesis using ${ }^{15} \mathrm{~N}$ amino acid labeling in pancreatic cancer cells. Anal Chem 2009, 81:2.

25. Xiao GG, Nel AE, Loo JA: Nitrotyrosine-modified proteins and oxidative stress induced by diesel exhaust particles. Electrophoresis 2005, 26:1.

26. Xiao GG, Wang M, Li N, Loo JA, Nel AE: Use of proteomics to demonstrate a hierarchical oxidative stress response to diesel exhaust particle chemicals in a macrophage cell line. J Biol Chem 2003, 278:50.
27. Jiang XS, Tang LY, Cao XJ, Zhou H, Xia QC, Wu JR, Zeng R: Two-dimensional gel electrophoresis maps of the proteome and phosphoproteome of primitively cultured rat mesangial cells. Electrophoresis 2005, 26:23.

28. Callister SJ, Barry RC, Adkins JN, Johnson ET, Qian WJ, Webb-Robertson BJM, Smith RD, Lipton MS: Normalization approaches for removing systematic biases associated with mass spectrometry and label-free proteomics. J Proteome Res 2006, 5:2.

29. Ma D, Li S, Wang LS, Dai J, Zhao SL, Zeng R: Temporal and spatial profiling of nuclei-associated proteins upon TNF-alpha/NF-kappaB signaling. Cell Res 2009, 19:5

30. Chang C, Stewart RC: The two-component system. Regulation of diverse signaling pathways in prokaryotes and eukaryotes. Plant Physiol 1998, 117:3.

31. Barford D, Das AK, Egloff MP: The structure and mechanism of protein phosphatases: insights into catalysis and regulation. Annu Rev Biophys Biomol Struct 1998, 27:133.

32. Stock JB, Ninfa AJ, Stock AM: Protein phosphorylation and regulation of adaptive responses in bacteria. Microbiol Rev 1989, 53:4.

33. Cozzone AJ: Protein phosphorylation in prokaryotes. Annu Rev Microbiol 1988, 42:97.

34. Morrison DK: The 14-3-3 proteins: integrators of diverse signaling cues that impact cell fate and cancer development. Trends Cell Biol 2009, 19:1.

35. Yuan Z, Becker EB, Merlo P, Yamada T, DiBacco S, Konishi Y, Schaefer EM, Bonni A: Activation of FOXO1 by Cdk1 in cycling cells and postmitotic neurons. Science 2008, 319:5870.

36. Tzivion G, Gupta VS, Kaplun L, Balan V: 14-3-3 proteins as potential oncogenes. Semin Cancer Biol 2006, 16:3.

37. Porter GW, Khuri FR, Fu H: Dynamic 14-3-3/client protein interactions integrate survival and apoptotic pathways. Semin Cancer Biol 2006, 16:3.

38. Pak JH, Moon JH, Hwang SJ, Cho SH, Seo SB, Kim TS: Proteomic analysis of differentially expressed proteins in human cholangiocarcinoma cells treated with Clonorchis sinensis excretory-secretory products. J Cell Biochem 2009, 108:6.

39. Kang S, Shim HS, Lee JS, Kim DS, Kim HY, Hong SH, Kim PS, Yoon JH, Cho $\mathrm{NH}$ : Molecular proteomics imaging of tumor interfaces by mass spectrometry. J Proteome Res 2010, 9:2.

40. Basu A, Banerjee H, Rojas H, Martine SR, Roy S, Jia Z, Lilly MB, De León M, Casiano CA: Differential expression of peroxiredoxins in prostate cancer: consistent upregulation of PRDX3 and PRDX4. Prostate 2011, 71:7.

41. Obeid M, Panaretakis T, Tesniere A, Joza N, Tufi R, Apetoh L, Ghiringhelli F, Zitvogel L, Kroemer G: Leveraging the immune system during chemotherapy: moving calreticulin to the cell surface converts apoptotic death from "silent" to immunogenic. Cancer Res 2007, 67:17.

42. Kolch W, Pitt A: Functional proteomics to dissect tyrosine kinase signalling pathways in cancer. Nat Rev Cancer 2010, 9:618.

43. Etienne-Manneville S: From signaling pathways to microtubule dynamics: the key players. Curr Opin Cell Biol 2010, 22:1.

44. Zhang Z, Huang L, Zhao W, Rigas B: Annexin 1 induced by antiinflammatory drugs binds to NF-kappaB and inhibits its activation: anticancer effects in vitro and in vivo. Cancer Res 2010, 70:6.

45. Lim LHK, Pervaiz S: Annexin 1: the new face of an old molecule. FASEB J 2007, 21:4

46. Mussunoor S, Murray Gl: The role of annexins in tumour development and progression. J Pathol 2008, 216:2

47. Lee WN, Guo P, Lim S, Bassilian S, Lee ST, Boren J, Cascante M, Go VL, Boros LG: Metabolic sensitivity of pancreatic tumour cell apoptosis to glycogen phosphorylase inhibitor treatment. Br J Cancer 2004, 91:12

48. Xiao J, Lee WN, Zhao Y, Cao R, Go VL, Recker RR, Wang Q, Xiao GG: Profiling pancreatic cancer-secreted proteome using $15 \mathrm{~N}$ amino acids and serum-free media. Pancreas 2010, 39:1

49. Zhao F, Mancuso A, Bui TV, Tong X, Gruber JJ, Swider CR, Sanchez PV, Lum JJ, Sayed N, Melo JV, Perl AE, Carroll M, Tuttle SW, Thompson CB: Imatinib resistance associated with $B C R-A B L$ upregulation is dependent on HIF-1alpha-induced metabolic reprograming. Oncogene 2010, 29:20.

50. Chen J, Röcken C, Nitsche B, Hosius C, Gschaidmeier H, Kahl S, Malfertheiner $P$, Ebert MPA: The tyrosine kinase inhibitor imatinib fails to inhibit pancreatic cancer progression. Cancer Lett 2006, 233:2.

51. Takayama Y, Kokuryo T, Yokoyama Y, Nagino M, Nimura Y, Senga T, Hamaguchi M: MEK inhibitor enhances the inhibitory effect of imatinib on pancreatic cancer cell growth. Cancer Lett 2008, 264:2.

52. Mahalingam D, Giles F: Challenges in developing targeted therapy for pancreatic adenocarcinoma. Expert Opin Ther Targets 2008, 12:11. 
53. Riveraemail F, López-Tarruella S, Vega-Villegas ME, Salcedo M: Treatment of advanced pancreatic cancer: from gemcitabine single agent to combinations and targeted therapy. Cancer Treat Rev 2009, 35:4.

54. Choi H, Chang J-W, Jung Y-K: Peroxiredoxin 6 interferes with TRAILinduced death-inducing signaling complex formation by binding to death effector domain caspase. Cell Death Differ 2011, 18:3.

55. Wang M, Xiao GG, Li N, Xie Y, Loo JA, Nel AE: Use of a fluorescent phosphoprotein dye to characterize oxidative stress-induced signaling pathway components in macrophage and epithelial cultures exposed to diesel exhaust particle chemicals. Electrophoresis 2005, 26:11.

56. Zreiqat H, Howlett CR, Gronthos S, Hume D, Geczy CL: S100A8/S100A9 and their association with cartilage and bone. J Mol Histol 2007, 38:5.

57. Mendonça G, Mendonça DBS, Aragão FJL, Cooper LF: The combination of micron and nanotopography by $\mathrm{H}(2) \mathrm{SO}(4) / \mathrm{H}(2) \mathrm{O}(2)$ treatment and its effects on osteoblast-specific gene expression of hMSCs. J Biomed Mater Res A 2010, 94:1.

58. Deng FY, Liu YZ, Li LM, Jiang C, Wu S, Chen Y, Jiang H, Yang F, Xiong JX, Xiao P, Xiao SM, Tan L, Sun X, Zhu XZ, Liu MY, Lei SF, Chen XD, Xie JY, Xiao GG, Liang SP, Deng HW: Proteomic analysis of circulating monocytes in Chinese premenopausal females with extremely discordant bone mineral density. Proteomics 2008, 8:20.

59. Pratt JM, Petty J, Riba-Garcia I, Robertson DHL, Gaskell SJ, Oliver SG, Beynon RJ: Dynamics of protein turnover, a missing dimension in proteomics. Mol Cell Proteomics 2002, 1:8.

60. Xiao GG, Garg M, Lim S, Wong D, Go VL, Lee WN: Determination of protein synthesis in vivo using labeling from deuterated water and analysis of MALDI-TOF spectrum. J Appl Physiol 2008, 104:3.

61. Vander Heiden MG, Cantley LC, Thompson CB: Understanding the Warburg effect: the metabolic requirements of cell proliferation. Science 2009, 324:5930.

doi:10.1186/2162-3619-2-18

Cite this article as: Wang et al:: Inhibition of transketolase by oxythiamine altered dynamics of protein signals in pancreatic cancer cells. Experimental Hematology \& Oncology 2013 2:18.

\section{Submit your next manuscript to BioMed Central and take full advantage of:}

- Convenient online submission

- Thorough peer review

- No space constraints or color figure charges

- Immediate publication on acceptance

- Inclusion in PubMed, CAS, Scopus and Google Scholar

- Research which is freely available for redistribution 